\title{
The vulnerability of Brazilian female prisoners to HIV infection
}

L. Strazza1,
R.S. Azevedo ${ }^{2}$,
H.B. Carvalho
and E. Massad
${ }^{1}$ Laboratório de Investigação Médica, LIM-01, Hospital das Clínicas, and Departamentos de ${ }^{2}$ Patologia, ${ }^{3}$ Medicina Preventiva and ${ }^{4}$ Medicina Legal, Faculdade de Medicina, Universidade de São Paulo, São Paulo, SP, Brasil

\section{Correspondence \\ L. Strazza \\ Disciplina de Informática Médica LIM-01, HC, FM, USP \\ Av. Dr. Arnaldo, 455, 3o andar \\ 01246-903 São Paulo, SP \\ Brasil \\ Fax: $+55-11-3081-7717$ \\ E-mail: strazza@usp.br}

Presented at the 1st Symposium on Advances in Medical Research, Institute of Medical Investigation Laboratories, HC-FMUSP, São Paulo, SP, Brazil, March 21-22, 2003.

Research supported by PRONEXCNPq. L. Strazza was supported by FAPESP (No. 99/11162-2). E. Massad and R.S. Azevedo were partially supported by CNPq.

Received June 12, 2003 Accepted March 15, 2004

\begin{abstract}
The purpose of the present study was to determine the vulnerability of women in prison to HIV infection. The study was carried out from August to October 2000 in a São Paulo State Penitentiary, where 299 female prisoners were serving time. We interviewed and obtained a blood sample from 290 females who agreed to enter the study. Sera were tested for the presence of antibodies to HIV, hepatitis $\mathrm{C}$ virus (HCV) and syphilis and the odds ratio (OR) was calculated for variables related to HIV positivity on the basis of a questionnaire. The overall prevalence data were: $13.9 \%$ for HIV (37 of 267), $22.8 \%$ for syphilis (66 of 290), and 16.2\% for HCV (47 of 290). Sexual partnership variables were significantly related to HIV infection. These included HIV-positive partners $(\mathrm{OR}=7.36, \mathrm{P}=0.0001)$, casual partners $(\mathrm{OR}=8.96, \mathrm{P}=0.009)$, injectable drug user partners $(\mathrm{OR}=$ $4.7, \mathrm{P}=0.0001)$, and history of sexually transmitted disease $(\mathrm{OR}=$ $2.07, \mathrm{P}=0.05)$. In addition, a relationship was detected between HIV infection and drug use $(\mathrm{OR}=2.48, \mathrm{P}=0.04)$ and injectable drug use $(\mathrm{OR}=4.2, \mathrm{P}=0.002)$. Even women with only one partner presented a significant $\mathrm{OR}$ for $\mathrm{HIV}$ infection $(\mathrm{OR}=2.57, \mathrm{P}=0.009)$, reflecting their vulnerability due to their trust in their partner, who did not use a condom. Although the use of injectable substances is associated with HIV infection, our results point to sexual behavior as the most important component of HIV transmission in the female prisoner population.
\end{abstract}

Key words

- HIV

- HCV

- Syphilis

- Vulnerable populations

- Women

- Prisoners

\section{Introduction}

In the $1980 \mathrm{~s}$, the woman/man ratio for new cases of HIV infection in São Paulo State, Brazil, was $1 / 27$, with a progressive change to $1 / 3$ by the mid-1990s $(1,2)$. Recent data published by the Epidemiological Surveillance Center of DST and AIDS, in São Paulo State (3), showed that the cases notified in 2001 were 1113 for women and 2135 for men, corresponding to a continuation of the $1 / 2$ trend for the woman/man ratio of new cases observed during the last 5 years.

Women are considered to be a population particularly vulnerable to infections, especially sexually transmitted diseases (STD) $(4,5)$. The rapid increase in STD and acquired immunodeficiency syndrome (AIDS) is more noticeable among inmates of correctional facilities than among the general popu- 
lation (6,7). Many behavioral studies have provided evidence for significant rates of risk behavior in correctional settings $(5,8)$. The problem has been fueled by the rapidly increasing incidence of human immunodeficiency virus (HIV) infection and AIDS among prisoners in many countries (9). About 17\% of AIDS cases notified in the US in 19961997 were for inmates of the penal system. About 8900 inmates of American prisons, in 1997, had AIDS and 35 to 47 thousand had HIV (4,10). Since the beginning of the 1990's, AIDS has been one of the major causes of death among women aged 25 to 49 years in Brazil (1,2). In addition, from 1996 to 1999 there was an increase from 3 to $22 \%$ of the prevalence of syphilis among women in the US penal system (11).

Some studies $(4,12-19)$ carried out on female and male prisoners in American correctional prison systems and in penitentiaries in different countries have shown that serology for syphilis and hepatitis $\mathrm{C}$ virus (HCV) gave indirect information about the route of transmission of HIV infection.

Thus, the objective of the present study was to determine the risk factors for HIV infection among women prisoners before and during their time in a penitentiary by measuring the seroprevalence of the virus in a State Penal Institution in São Paulo, Brazil and by applying a questionnaire concerning habits and sexual behavior.

\section{Material and Methods}

The study was carried out in a Reference Prison, the Butantã Female Penitentiary, located on Rodovia Raposo Tavares, km 19.5, in Jardim Arpoador-Butantã, São Paulo city. The prison utilizes two systems: normal prison with capacity for 208 women and a minimum security section for 298 female prisoners.

From August to October 2000 we contacted 299 prisoners from the two systems, 290 of whom agreed to participate in the study. All individuals recently admitted to the institution were included in the study during the two months we visited the penitentiary. They were included in order to provide evidence about the epidemiological background of this population, i.e., the extent and scope of HIV infection in the community from which the inmates originate, and, perhaps more importantly, to allow comparisons with previous studies. Participation in the study was voluntary and confidentiality was guaranteed.

Twenty-three of the 290 inmates refused to participate in anti-HIV screening. They said they were not interested in knowing their serological condition at that time, a reason also given to other investigators $(20,21)$, but they agreed to be tested for syphilis and HCV. Thus, 267 inmates were submitted to the anti-HIV test and 290 were submitted to anti-syphilis and anti-HCV tests.

Since we did not know if the 290 prisoners were illiterate or not, they were interviewed face-to-face (22) using a questionnaire that covered their sex practices and those of their partners, use of illicit drugs, and knowledge of STDs and AIDS adapted from an injecting drug users study in Santos, Brazil (23).

Blood was collected by a nurse and the interviews were conducted by five psychologists previously trained by the psychologist in charge of the project. The results of the serological tests were delivered directly to the prisoners. The administrative staff of the prison did not have access to the replies to the individual questionnaires or to the results of the serological tests, but the latter were promptly reported to the medical staff responsible for the care of the female prisoners.

\section{Laboratory tests}

Serum samples were tested for antibodies against HIV types 1 and/or 2 (HIV-1 and HIV-2) using a commercial enzyme-linked 
immunosorbent assay (Ortho HIV-1/HIV-2 Ab-Capture ELISA Test System, Ortho-Clinical Diagnostics Inc., East Bridgewater, NJ, USA). The presence of anti-HIV antibodies was confirmed in samples with a positive ELISA using a commercial immunoblotting assay (New Lav Blot I, Sanofi Diagnostics Pasteur S.A., Marnes la Coquette, France).

Seroprevalence for hepatitis $\mathrm{C}$ was determined by a commercially available enzymelinked immunoassay (Murex anti-HCV version 4.0, Murex Biotech Limited, Abbott Diagnostics Division, Dartford, UK). Antibodies against Treponema pallidum were determined by a commercial enzyme immunoassay kit (ICE* Syphilis, Murex Biotech Limited, Abbott Diagnostics Division).

Cut-off values were determined according to manufacturer instructions for each batch, and results were recorded qualitatively as follows: if the absorbance of a serum sample was above the cut-off calculated for the batch, the subject was classified as seropositive (presence of antibodies against a given pathogen) and if the absorbance was equal to or below the cut-off, the subject was classified as seronegative.

\section{Ethical aspects}

The project was approved by CAPPesq/ HCFMUSP (No. 771/99) on May 10, 2000 and the female prisoners who participated in the study signed an informed consent term. The confidentiality of all information was guaranteed and the results of the serological tests were given only to the interested prisoner by the researchers. The prisoners were instructed to contact the medical staff of the penitentiary assistance when appropriate.

\section{Statistical analysis}

The association between HIV, HCV and syphilis markers and questionnaire variables was tested by cross-tabulating the data in a bivariate analysis and by applying the $\chi^{2}$ test or Fisher's exact test and calculating the odds ratio $(\mathrm{OR})$ and $\mathrm{P}$ value. Logistic regression was performed by analyzing HIV prevalence against independent variables and by employing stepwise backward analysis techniques. The EPI-INFO, version 6, and Stata 8.0 software was used.

\section{Results}

The prevalence estimates for HIV, hepatitis $\mathrm{C}$ and syphilis in this group of female prisoners are presented in Table 1. Only 17 of the 290 prisoners knew their serology status for HIV before this study was performed. All women known to be HIV-positive were under treatment at the Penitentiary during the time of their imprisonment. An interesting fact was that among the $37 \mathrm{HIV}$ positive prisoners, only 8 thought that they were not at risk for HIV infection.

The age of the female prisoners included in the sample ranged from 18 to 65 years (mean \pm SD: $31.0 \pm 9$; median: 29 years); $40 \%$ (116 of 290) had been arrested before, $53 \%$ (147 of 279) were single, 58\% (94 of 162) had children, $41.4 \%$ (91 of 220 ) were taking the pill for birth control, 56\% (156 of 279 ) were white, $52.7 \%$ (147 of 279) had completed primary school, 40.1\% (112 of 279) had completed high school, $6.5 \%$ (18 of 279) were illiterate, and $0.7 \%$ (2 of 279) had higher education (2 lawyers).

The population was highly heterogenous, with very distinct patterns of crimes committed. The most common crime was burglary/ robbery $(50.3 \%$ were imprisoned based on

Table 1. Seroprevalence of HIV, HCV and syphilis among female prisoners at the Butantã Women's Penitentiary, São Paulo, Brazil, in 2000.

\begin{tabular}{lccc}
\hline & HIV & HCV & Syphilis \\
\hline Number of prisoners & 267 & 290 & 290 \\
Seropositive & 37 & 47 & 66 \\
Prevalence & 0.139 & 0.162 & 0.230 \\
$95 \% \mathrm{Cl}$ & $0.097-0.180$ & $0.119-0.205$ & $0.179-0.276$
\end{tabular}


Table 2. Frequency of female prisoners who maintain sexual intercourse out of and in the Butantã Women's Penitentiary, according to gender of the partners.

\begin{tabular}{lcc}
\hline Partner gender & Out (\%) & In (\%) \\
\hline Female & $13(4.7)$ & $59(24.0)$ \\
Male & $228(82.3)$ & $28(11.4)$
\end{tabular}

Sixty-three percent of the prisoners had no sexual activity in the penitentiary.

Table 3. Drug use profile among female prisoners and their partners, as reported by the female personers, in the Butantã Women's Penitentiary, São Paulo, Brazil.

\begin{tabular}{lcc}
\hline Drug & Prisoners (\%) & Partners (\%) \\
\hline Marijuana & $163(61)$ & $143(52)$ \\
Cocaine & $130(47)$ & $105(38)$ \\
Crack-cocaine & $119(43)$ & $88(32)$ \\
Inhalants & $108(39)$ & $14(5)$ \\
LSD & $19(7)$ & $9(3)$ \\
Amphetamine & $18(7)$ & $11(4)$ \\
Hashish & $7(2)$ & $0(0)$
\end{tabular}

Table 4. Injectable drug use (IDU) profile among prisoners in the Butantã Women's Penitentiary, São Paulo, Brazil.

\begin{tabular}{lrc}
\hline Question & \multicolumn{2}{c}{ Answer } \\
\cline { 2 - 3 } & Yes & No \\
\hline Use of injectable drugs & $9 \%(24)$ & $91 \%(239)$ \\
Syringe sharing & $44 \%(11)$ & $56 \%(14)$ \\
Sex with injecting drug user & $15 \%(41)$ & $91 \%(216)$
\end{tabular}

Table 5. History of past and present sexually transmitted diseases (STD) reported by the prisoners in the Butantã Women's Penitentiary, Sao Paulo, Brazil, and their knowledge of their partners having STD.

\begin{tabular}{lcr}
\hline Disease & $\begin{array}{c}\text { \% Prisoners } \\
(\mathrm{N}=61)\end{array}$ & $\begin{array}{c}\text { \% Partners } \\
(\mathrm{N}=24)\end{array}$ \\
\hline Syphilis & $11.50(7)$ & $25.0(6)$ \\
Gonorrhea & $6.55(4)$ & $12.5(3)$ \\
Yellow discharge & $8.20(5)$ & $8.5(2)$ \\
Condyloma & $1.65(1)$ & $4.2(1)$ \\
Other genital lesions treated & $1.65(1)$ & $8.5(2)$ \\
Itching & $8.00(4)$ & $8.5(2)$ \\
Treated for unknown STD & $13.11(8)$ & $33.3(8)$ \\
Not answered & $1.63(31)$ & -
\end{tabular}

articles 157 and 155 of the Brazilian Penal Code), followed by drug use and dealing (28.9\%, articles 12 and 14$)$. The replies to questions about sex and drugs can be considered to be of doubtful veracity because it is very difficult to talk about these subjects with persons who are prisoners.

Table 2 shows the sex habits of the women interviewed when they were out of the penitentiary and when they were imprisoned. It is interesting to point out that there were occasional reports of homosexuality, given the absence of male partners during imprisonment.

Concerning drug abuse, the female prisoners stated that they use more illicit drugs than their partners, as shown in Table 3. The injecting drug use (IDU) profile of this group is shown in Table 4. IDU was much less frequent among these prisoners than among their partners (9 and 15\%, respectively). However, when the prisoner reported having an IDU partner, her risk of HIV and HCV infection was higher, with an OR of 4.72 and 8.16 , respectively $(\mathrm{P}<0.0001)$.

Twenty-two percent of the female prisoners (61 of 276) were aware of having had at least one STD, with syphilis being the most frequent (11.5\%, 7 of 61$)$. Among these women, $8.7 \%$ (24 of 276 ) knew their partners had an STD, and again syphilis was in first place, with a frequency of $25 \%$ (6 of 24 male partners). Complete data are shown in Table 5.

The OR for HIV infection was calculated by crossing each questionnaire variable with HIV serostatus (bivariate analysis), and the statistically significant results are shown in Table 6. It can be seen that variables related to sexual partnership had significantly higher $\mathrm{P}$ values for OR. HIV infection was associated with $\mathrm{HCV}$ infection $\left(\mathrm{OR}=3.48 ; \chi^{2}=\right.$ $10.8, \mathrm{P}=0.001)$, but no association was found between HIV and syphilis.

Logistic analysis was applied to the variables shown in Table 6, plus HCV serostatus and age. In the final model all variables were 
removed except for the IDU partner, with a statistically significant $\mathrm{OR}=20.7(2.6-163.8)$ $(\mathrm{P}=0.04)$.

We also performed another logistic analysis including the same independent variables except HCV serostatus, which was entered as a dependent variable. Again, in the final model all variables were removed except the IDU partner, with a higher and even more significant $\mathrm{OR}=36$ (3.34-388.2) $(\mathrm{P}=0.003)$.

\section{Discussion}

The prevalence of HIV was $13.85 \%$ among female prisoners, a value higher than that reported by Azevedo in 1999 (15) for disadvantaged young women aged 12 to 18 years arrested in São Paulo (10.3\%). The present value was lower than that reported by Ferreira (13) in a study of female prisoners of the São Paulo State Penitentiary conducted from 1994 to 1995, which was 20.6\%, but was similar to that reported by Lopes et al. (4) for the same penitentiary in a study conducted from 1997 to 1998 (14.5\%).

The present study provides some quantitative information about the likely route of HIV transmission among these female prisoners. As shown by the OR, by bivariate analysis and by logistic regression, sexual partnership seems to be the most important risk of acquiring HIV.

These data are in contrast with those reported by Massad et al. (16) for male prisoners, which showed that self-injection of illicit drugs was the main route of HIV transmission. Gender, that can reflect different social habits and risk behaviors, seems to play a role in HIV transmission, and therefore different approaches should be used for men and women.

According to Dixon (24), confinement is considered to be a unique moment in the
Table 6. Statistically significant risk behaviors for HIV infection after calculation of the odds ratio (OR) for each questionnaire variable related to HIV seropositivity.

\begin{tabular}{lrrlllll} 
Behavior & $\mathrm{n}$ & $\mathrm{N}$ & $\% \mathrm{HIV}+(\mathrm{x})$ & $\mathrm{OR}$ & $95 \% \mathrm{Cl}$ & $\chi^{2}$ & $\mathrm{P}$ \\
\hline Partner was IDU & 35 & 236 & $38(12)$ & 4.7 & $1.87-11.89$ & 15.1 & 0.0001 \\
Partner was HIV+ & 14 & 248 & $20(7)$ & 7.36 & $2.1-25.9$ & 15.8 & 0.0001 \\
Fixed partner & 68 & 255 & $44(16)$ & 2.57 & $1.16-5.68$ & 6.8 & 0.009 \\
Casual partners & 13 & 59 & $63(5)$ & 8.96 & $1.42-62.81$ & - & 0.009 \\
Prisoner is IDU & 21 & 242 & $22(8)$ & 4.2 & $1.42-12.2$ & 9.8 & 0.002 \\
Prisoner uses drugs & 187 & 267 & $84(31)$ & 2.48 & $0.93-7.02$ & 3.98 & 0.04 \\
Previous STD & 60 & 255 & $36(13)$ & 2.07 & $0.9-4.7$ & 3.69 & 0.05
\end{tabular}

IDU = injectable drug user; STD = sexually transmitted diseases. Fisher's exact test.

lifetime of female prisoners, when they can take care of their body and health and learn about prevention. However, it is an accepted fact that confinement increases the risk of the acquisition of STDs, including HIV infection $(5,25-30)$.

Wolfe et al. (31) and Perez-Molina et al. (32) pointed out the spread of HIV to this floating population, bringing their diseases with them from one prison to another when they are transferred.

The prevalence of HIV (13.85\%) observed in the present study also reflects the virtual absence of prevention programs directed toward the prison population. In addition, even though female prisoners have been regularly tested for HIV during the last decade, only a small fraction (less than 5\%) knew about their HIV serostatus at the time of the present study.

Our data confirm the increase of HIV infection among women, mainly by sexual transmission, as demonstrated by the strong correlation of HIV seroprevalence and sexual vulnerability with their partners, in addition to high syphilis seroprevalence. The present results also emphasize the need for educational and adequate prevention programs directed at the female and male prison population in order to reduce the vulnerability of women to HIV/AIDS and STDs. 


\section{References}

1. Coordenação Nacional de DST/AIDS (1998). AIDS no Brasil: Um Esforço Conjunto, Governo e Sociedade. Ministério da Saúde do Brasil, Brasília, DF, Brazil.

2. Centro de Vigilância Epidemiológica (1998). Boletim Epidemiológico AIDS. Secretaria de Estado da Saúde de São Paulo, São Paulo, SP, Brazil.

3. Centro de Referência e Tratamento de DST/AIDS (2002). Boletim Epidemiológico Ano XXI, Número 1. Secretaria de Estado da Saúde de São Paulo, São Paulo, SP, Brazil.

4. Lopes F, Latorre MR, Pignatari ACC \& Buchalla CM (2001). HIV, HPV and syphilis prevalence in a women's penitentiary in the city of São Paulo, 1997-1998. Cadernos de Saúde Pública, 17: 1473-1480.

5. Simbulan NP, Aguilar AS, Flanigan T \& Uvin SC (2001). High-risk behaviors and the prevalence of sexually transmitted diseases among women prisoners at the women state penitentiary in Metro Manila. Social Science and Medicine, 52: 599-608.

6. Calzavara L \& Burchell A (1999). Developing effective HIV prevention programs for inmates: results from an Ontario-wide survey. Canadian HIV-AIDS Policy and Law Newsletter, 5: 32-34, 39-42.

7. Kassira EN, Bauserman RL, Tomoyasu N, Caldeira E, Swetz A \& Solomon $L$ (2001). HIV and AIDS surveillance among inmates in Maryland prisons. Journal of Urban Health, 78: 256-263.

8. Horsburgh CR, Jarvis JQ, McArthur T, Inacio T \& Stock P (1990). Seroconversion to human immunodeficiency virus in prison inmates. American Journal of Public Health, 80: 209-210.

9. Dolan K, Wodak A \& Penny R (1995). Aids behind bars: preventing HIV spread among incarcerated drug injectors. AIDS, 9: 825-832.

10. Skolnick AA (1998). Look behind bars for key to control of STDs. Journal of the American Medical Association, 279: 97-99.

11. Altman MIS (1999). Much more AIDS in prisons than in general population. New York Times, New York, 9 January, 14.

12. Vaz RG, Gloyd S, Folgosa E \& Kreiss J (1995). Syphilis and HIV infection among prisoners in Maputo, Mozambique. International Journal of STD and AIDS, 6: 42-46.

13. Ferreira MMC (1997). Infecção pelos retrovírus HIV-1, HTLV-I e HTLV-II na população feminina da penitenciária do estado de São Paulo: prevalência, fatores de risco e conhecimento desse risco. Doctoral thesis, Departamento de Epidemiologia, Faculdade de Saúde Pública, Universidade de São Paulo, São Paulo, SP, Brazil.

14. Rozman M, Massad E, Silveira AS et al. (1998). HIV/AIDS in a Brazilian prison. International Journal of STD and AIDS, 9: 183-184.

15. Azevedo LS (1999). Diferenças de gênero e risco para a infecção pelo HIV em adolescentes internos na Fundação Estadual Para o Bem Estar do Menor de São Paulo FEBEM. Master's thesis, Programa de Fisiopatologia Experimental, Faculdade de Medicina, Universidade de São Paulo, São Paulo, SP, Brazil.

16. Massad E, Rozman M, Azevedo RS, Silveira AS, Takey K, Yamamoto YL, Strazza L, Ferreira MM \& Burattini MN (1999). Seroprevalence of HIV, HCV and syphilis in Brazilian prisoners: preponderance of parenteral transmission. European Journal of Epidemiology, 15: 439-445.

17. Blank S, Sterberg M, Neylans LL, Rubin SR, Weisfuse IB \& St. Louis ME (1999). Incident syphilis among women with multiple admissions to jail in New York city. Journal of Infectious Diseases, 180: 1159-1163.

18. Miranda AE, Vargas PM, St. Louis ME \& Viana MC (2000). Sexually transmitted diseases among female prisoners in Brazil: prevalence and risk factors. Sexually Transmitted Diseases, 27: 491-495.

19. Rich JD, Hou JC, Charuvastra A, Towe CW, Lally M, Spaulding A Bandy U, Donnelly EF \& Rompalo A (2001). Risk factors for syphilis among incarcerated women in Rhode Island. AIDS Patient Care and STDs, 15: 581-585.

20. Smith PF, Mikl J, Truman BI, Lessner L, Lehman JS, Stevens RW, Lord EA, Broaddus RK \& Morse DL (1991). HIV infection among women entering the New York State Correctional System. American Journal of Public Health, 81 (Suppl): 35-40.

21. Beltrami JF, Cohen DA, Hamrick JT \& Farley TA (1997). Rapid screening and treatment for sexually transmitted diseases in arrestees: a feasible control measure. American Journal of Public Health, 87: 1423-1426.

22. Catania JA, Kegeles SM \& Coates TK (1990). Towards an understanding of risk behavior: an AIDS risk reduction model (ARRM). Health Education Quarterly, 17: 53-72.

23. Carvalho HB, Mesquita F, Massad E, Bueno RC, Lopes GT, Ruiz MA and Burattini MN (1994). HI V and infections of similar transmission patterns in a drug injectors community of Santos Brazil. Journal of Acquired Immune Deficiency Syndrome, 12: 84-92.

24. Dixon PS, Flanigan TP, De Buono BA, Laurie JJ, De Ciants ML, Hoy J, Stein M, Scott H, Denman N \& Carpenter CCJ (1993). Infection with the human immunodeficiency virus in prisoners: meeting the health care challenge. American Journal of Medicine, 95: 629-635.

25. Shafer MA, Hilton J, Ekstrand M, Keogh J, Gee L, DiGiorgio-Haag L, Shalwitz J \& Schachter J (1993). Relationship between drug and sexual behaviors and the occurrence of STDs among high-risk male youth. Sexually Transmitted Diseases, 20: 307-313.

26. Shafer MA (1994). Sexual behavior and sexually transmitted diseases among male adolescents in detention. Sexually Transmitted Diseases, 21: 181-182.

27. Rotily M, Pujol AG, Obadia Y, Moatti JP, Toubiana P, Vaiasse CV \& Gastaut JA (1994). HIV testing, HIV infection and associated risk factors among inmates in south-eastern French prisons. AIDS, 8: 1341-1344

28. Martin V, Gozalez P, Caylá JA, Mirabent J, Cañellas J, Pina JM \& Miret $P$ (1994). Case finding of pulmonary tuberculosis on admission to a penitentiary centre. Tubercle and Lung Disease, 75: 49-53.

29. Morris RE, Harrison EA, Knox GW, Tromanhauser E, Marquis DK \& Watts LL (1995). Health risk behavioral survey from 39 juvenile correctional facilities in the United States. Journal of Adolescent Health, 17: 334-344.

30. Canterbury RJ, McGarvey EL, Shedonkeller AE, Waite D, Reams P \& Koopman C (1995). Prevalence of HIV related risk behaviors and STDs among incarcerated adolescents. Journal of Adolescent Health, 17: 173-177.

31. Wolfe MI, Xu F, Patel P, O'Cain M, Schillinger JA, St. Louis ME \& Finelli $L$ (2001). An outbreak of syphilis in Alabama prisons: correctional health policy and communicable disease control. American Journal of Public Health, 91: 1220-1225.

32. Perez-Molina JA, Fernandez-Gonzalez F, Hernangomez S, Gonzalez C, Miralles P, Lopez-Bernaldo de Quiros JC \& Bouza E (2002). Differential characteristics of HIV-infected penitentiary patients and HIV-community patients. HIV Clinical Trials, 3: 139-147. 